\title{
Reading as a Method of Language Learning among L2/First Additional Language Learners: The Case of English in one High School in Alice
}

\author{
John Wankah Foncha
}

University of Fort Hare, Alice 5700

\section{Doi:10.5901/mjss.2014.v5n27p675}

\section{Abstract}

Reading is considered as one of the most critical skills for learners to succeed in their academic pursuits. In view of this, this study attempts to find various strategies to inculcate the reading culture in learners. Methodologically, the study is premised within the community engagement project of the researcher through observation and informal interviews. The study shows that reading is a serious problem among learners partly because of the high illiteracy rate and partially because of the use of First Additional Language as the language of teaching and learning. The study used critical Discourse Analysis within interpretivism to bring out the perspectives of the researcher on how reading could be made exciting among the learners. The findings showed that there is need for parents, teachers and the community at large to motivate reading among learners for they say charity begins from home. Furthermore, it was suggested that once an interest in reading is developed and the learners have a positive attitude towards reading, then it can become a culture among them. The study concludes that reading needs to be taught as social practice so as to reduce the level of anxiety among the learners.

\section{Introduction/Background}

In a typical South African classroom situation, English dominates since it is used as the medium of instruction. In this regard, the CAPS curriculum therefore obliges the teaching of all subjects in English, learner's first additional language. In view of this, the learners do not have any choice but to communicate and interact with each other using English despite the fact that it is FAL to most of them (CAPS, 2012). This affects more students particularly those who were not fortunate enough to be exposed to English at early age (Banda, 2009) and they may become afraid to express themselves freely since they struggle with speaking, listening, reading and writing English which can lead to poor response to any given text. This is posing serious problems with teaching and learning and there is need to seek ways to encourage and instil reading culture in FAL learners since reading is seen as one of the easiest ways through which to learn a new language. It is in this light that this paper wishes to find ways by which reading culture can be inculcated in the learners. Thus, the study is eager to propose how language context could influence both language preference and language behaviours on conditions under which languages are learnt and used both in formal and informal contexts with specific reference to reading and response (Sivasubramaniam, 2004). In this study, EFAL students use English in formal conditions, because it is the lingua franca in the institutions of higher learning (CAPS, 2012).

South Africa is a multilingual country with eleven official languages- nine indigenous languages and the two former colonial languages of English and Afrikaans-recognised as official languages in the Constitution of 1996 (South Africa,1996).In the Eastern Cape Province where this study was conducted, the main language, isiXhosa, is the home language of $83,8 \%$ of the population and English speakers are 3,7\%.(Probyn et al., 2002). They also confirm that African learners use their home language in their homes and communities. To make matters worse, the demographics suggest that they have little direct contact with home language English speakers.

According to Abongdia (2013) the globalisation of English has resulted in "forms of linguistic beliefs and practices that accent the socio-political dimensions of language variation" and "is rooted in contexts of social injustice". As a result, the socio-political situation of the different African countries plays a great role in the beliefs they hold about languages. In view of this, Foncha (2013) thinks that English has achieved a dominant position in the world as the global lingua franca and the language of economic and political activities. Allmann (2009:29) sees English as a "permanent element of developing Africa" despite its different dialects.

Township schools perceive that they are losing learners to previously 'white' schools in the suburbs because their parents want them educated in English and in order to counter this trend offering English medium of instruction from Grade 1. De Klerk (2002) states that although access to English is one of the factors motivating township parents to send 
their children to former white schools, they were also motivated by the expectation that these schools would provide better resourced and more stable learning environments. Nowadays educators are facing the challenges to meet the needs of the large number of learners whose primary language is not English (Gibbons, 2003). Despite this diversity of languages, the medium of instruction is still English.

Most School Governing Bodies (SGBs) through democratic processes as enshrined in the Constitution of South Africa, Act 108 of 1996 Sec 29 (1), National Education Policy Act, Act 27 of 1996 and the South African Schools' Act, 84 of 1996, Sec (6) (2), opted for English as the language of teaching and learning without any consideration as to whether the learners were able to learn effectively (Din Yan, 2003: 4). Such a decision appears to be justified in terms of the need for English language skills for either local or international career advancement (Jenkins, 2003) which is why English is generally regarded internationally as the language of power, commerce, industry and education.

The commonest means of communication among learners is the use of the mother tongue isiXhosa in and outside the classroom contexts. This in a way demotivates them from reading text written in English, the language of teaching and learning. Some teachers use their mother tongue even when they teach English as a subject and content subjects as well. In view of this, it is ironic that at the end of the courses, learners are assessed in English. The greatest enemy to the reading culture from these communities is the lack of libraries and so they are not exposed to reading.

\section{Methodologies}

The study is based on the observation of Grades 10,11 and 12 of one high school in Alice where the researcher was teaching and training other community members as part of researcher's community engagement how to teach English first additional language. The researcher noticed that the learners did not have interest in reading and was trying to understand where the lack of interested emanated. The paper is also keen to see how the interest in reading can be kindled in the learners because such an interest in the researcher's experience helped to improve their academic performance in all the subjects. Thus the different strategies used to instil reading culture became the instruments for data collection.

\section{Review of Literature}

According to McKay (2002) it is not the number of native speakers of English, but the large number of non native speakers of English who make it "a language of wider communication', thus, an international language. Mckay further suggests the four reasons why English is an international Language:

- English is used as a communicative language both internationally and globally within multilingual societies.

- It is no longer connected to cultures.

- It becomes embedded in the culture of the particular country which it is used.

- Its function is to enable speakers to share their ideas and cultures too.

Jenkins (2003) states that English as International Language is a concept of the English language being seen as a global means of communication in numerous dialects, and also the movement towards an international standard for the language. It is also referred to as Global English, World English, Common English, Continental English and General English which is regarded as English as an associate language. These terms refer simply to the array of varieties of English spoken throughout the world (Jenkins, 2003). It is worthy to propose right from this juncture that English plays the role of unifying diversity in South Africa since it is a minority language in terms of native speakers and standardised above all the other languages. In this regard, English is deemed to be very appropriate for teaching and learning in higher institutions as well as for wider communication. This view is meant to suggest the learning of a language as a social practice.

Smith (2003) states that the domination of the English language globally is undeniable. English is the language of diplomacy and international communications, business, tourism, education, science, computer technology, media and Internet. Based on the argument proceeding, English is used to develop communication, technology, programming, software, etc. In short, it dominates the web as $70 \%$ of all information stored electronically is in English (Smith, 2003). This function of the English language in a way acts as instrumental and or integrated motivation for non-native speakers of English to learn the language.

Language Learning nowadays focuses on a context of meaning unlike in the old days when the major focus was on grammar only. This is based on the fact that traditional grammar is seen as prescriptive because it focuses on the distinction between what people do with language and what they ought to do with it, according to pre-established norms 
and standards (Dudeney, 2003). The principal goal of traditional grammar, therefore, is perpetuating a historical model of what supposedly constitutes proper language. But the prescriptive rules have to be amended occasionally to reflect not only changes in the language but also research that proves traditional advice may have been inaccurate (Sivasubramaniam, 2004). In view of the above, the current study is more interested on context of communication rather than prescriptive grammar hence language learning as a social practice becomes the lens through which the study understands language learning and language acquisition. Thus, understanding a text is based on the world views of the readers of the said text. In other words, one would expect diverse interpretations of a text based on the experiential knowledge of the students.

In view of the hegemonic nature of English, learners are therefore required to participate actively in class, joining in interactive language learning tasks and becoming autonomous learners in order to promote socialisation among them since they can acquire and understand language easily when they socialise with their peers (Foncha and Sivasubramaniam, 2014). This is the reason why Social Constructivists see reading, like learning as a social practice. This means that the social context affects when you read, what you read, where you read, who you read with and, of course, why and how you read. This is evidenced by Dudeney (2003) who observes that Interacting with text can involve practices as diverse as reading instructions, scanning a newspaper, or reading an academic article. It is the same way that responses emerge from the reading of a given text by a diverse classroom. This is meant to propose that, responses to the text are based on the experiential knowledge and the worldviews of the slearners to come up with interpretations.

In view of this, the following strategies are proposed to show how the social constructivist theory can be translated into actions for teaching in English First Additional Language (EFAL) classrooms. Dudeney (2003) states that the constructivists believe that learners learn best when they are actively engaged since they are viewed as those who act on objects and events within their environment and in the process gain understanding which derive meaning from those objects and events. This means that, the theory of constructivism looks at the way a learner learns. In the same light, Moerk, (1994) observes that educators should beware that the best way to learn is by having learners construct their own knowledge instead of having someone construct it for them. This is in contrast to the traditional and systemic functional grammars which insist on how to make meaning. That is to say that the interest of traditional grammar and systemic functional linguistics is stressed on how a language should be spoken instead of its communicative role. This is in contrast with the constructivist perspective which is more interested in the context of communication and the meaning made from communication.

The view above points toward the ecological perspective to language learning that is easily led by Affordances. With regard to the constructivist theory, learning is an active process of creating meaning from different experiences (Foncha, 2013). In other words learners can only learn best by trying to make sense from something on their own with the teacher as a guide to help them along the way. In view of this, the theory is extremely relevant to contemporary educational transformation and to the changes taking place in the institutional practices of South African Universities. This is evidenced by the state of flux within South African tertiary education. It is on this backdrop that the ecological view of language learning stresses the importance of a conducive environment for learning which is free from anxiety.

\subsection{The reading culture}

Reading culture can be regarded as the process that contributes and increases learners' positive attitude towards reading over a period of time (Nssien, 2008). Nssien (2008) further emphasise that reading culture is seen as the most important factor of students' success in education and in the modern complex society which imbibes reading as the basis of growth and development. Success in education is in this perspective synonymous to reading and writing. If one lacks the desire to read in this world today, then that person would be left behind since the world functions mainly through social media than through interpersonal interactions.

The starting point for learners to develop a positive attitude towards reading is through full support at early stage from the surroundings where they might have possibly been exposed to different strategies which would have made reading very interesting and to become part of their lives. In view of the constructivist, ecological perspectives and affordances, a conducive environment and harmonious atmosphere like home, school and peer groups reading, could be much effective since learners would have been exposed at early age by their parents, friends and teachers in the classroom. This exposure can shape their minds at early stage and they might be able to acquire basic skills in reading to become independent and competent at later stage. This is evidenced by Nwabueze (2011) who argues that an environment plays a very significant role in the development of reading culture in the learners. This means that a lack of proper exposure and support of children at early stage can affect them negatively and might result to bad attitude towards reading later on. 
It has been noted that children with positive reading attitudes tend to be willing and may volunteer to read because they enjoy it. This effect can lead to proficient and lifelong readers. On the other hand, children with poor attitudes toward reading may only read when they are forced to since they totally avoid reading and even refuse to read altogether (Satija, 2002). In this regard, the child's attitude toward reading may have a profound impact upon his or her overall academic performance.

Children should be educated so that they may become aware that reading is very important for the development of their language skills which may act as a factor that could influence the growth of their intellectual and emotional beings. Satija (2002) further observes that if the child is exposed enough to reading, he/she becomes empowered and knowledgeable and that can enable the child to participate freely in the social, religious, cultural and political life. It is within this eavesdrops that this researcher is anxious to find ways of instilling a positive reading attitude in the learners. In effect, it can only be achieved through a partnership between parents, teachers and more focused peers to elevate the culture of reading.

A child's success in school can be highly influenced by how much he/she is exposed by his/her parents to learning. This means that, the home environment plays a very significant role for laying a solid foundation in children' minds to become competent enough to overcome any challenges they might face throughout their lives. For example, children view their parents as experts and role models in everything they do. In view of this, Wood (2004) states that this builds trust, belief and confidence in children and the information and values that parents share with them about the importance of reading can significantly affect the attitudes that children develop.

Wood further adds that because children (particularly pres-scholars) always seek and desire approval from their parents, they tend to develop attitudes and values that parents would praise and reinforce. Ahamefule (2001) observes that it is not easy for a child to change drastically from what he/she was introduced to by the parents since they were first people who receive and take care of the child from birth throughout their childhood. Hence their influence can be very strong in the training of the child. Satija (2002) also supports the significant role played by parents in a child's development since parents can help to promote love for reading in their children at early stage by introducing them to activities like shared reading, reading aloud, and making printing materials available since this approach could promote positive attitudes towards literacy and can also eradicate the problems that they may be encountering with reading.

In line with the above, children's progress from early childhood through their school years may develop different feelings towards their school subjects. In the situation where children may not get that support from home towards school work, they might become discouraged and thus can develop negative attitudes which might forbid them from becoming successful due to poor performance and hence they may drop out from schools or universities. In view of this, the researcher thinks that children's progress from early childhood through their school years may develop different feelings towards their school subjects.

Like the home, the School environment should also be regarded as a second home for the child since this is the place where children spend more time with the teachers. In this regard, most children are eager to please their teachers as much as their parents (Ahamefule, 2001). This means that children can be quick to model the attitude and behaviours they observe in school, particularly from their teachers. This can help them to develop a positive attitude towards reading and as such, they can become confident and proficient because teachers teach reading directly and they also employ opportunities to reinforce the teaching. This approach can motivate learners who would try to read and continue to do so even if they might be facing any challenges because they have all the support they need from their teachers. Turner (1997) argues that the teacher should also show their learners love and care in order to make them feel valid and respected since the lack of love and care from the teachers can hinder learners from reading. When this happens, students can develop negative attitude towards reading as well as to all academic programmes. In this regard, it should be seen as promoting an educational climate that facilitates motivation and the desire to read in children.

This view point is further strengthened by Ezc (2006) who asserts that the role of a school is to be responsive to vast and variety needs of each child in the school environment. Ezc goes ahead to argue that teachers should use techniques in order to promote learners' voluntary reading. For example, they should provide a variety of high interest reading materials of various grade levels in the classroom: This can be accomplished by obtaining magazines, newspapers, books, dictionaries, encyclopaedias, and other reference materials that contain content that matches students' interests.

It is worthy of note that the above idea can highly shape children's attitudes toward reading by also providing systematic reinforcement (such as praise) when children are engaged in reading activities in the classroom. Trelease, (2006) is of the opinion that the above approaches and techniques can create a conducive and harmonious environment in the classroom (ecology and affordances) which in turn can help to nurture the students' intellects, interests and emotional development in the reading culture. In view of this, Pressley, (2002) thinks that, this can be acheived through 
providing functional libraries as well as educational environments which promote and encourage the interaction of literacy with other areas of the curriculum with all aspects of arts, reading, listening, speaking, viewing and writing. In extra ordinary situations where these resources might be scarce, particularly in rural areas, it is the teachers' responsibilities to make sure that they improvise. This means that teachers should have adequate skills in order to be creative and know exactly what is best for their students during teaching and learning. For example, they should be able to create relevant resources and provide conducive conditions to their students as well a harmonious atmosphere during lessons so that students can feel comfortable and secured where necessary.

Thirdly, Peer group plays a very significant role in a child's life and can influence the child's behaviour in different ways (either negative or positive) (Foncha and Sivasubramaniam, 2014). When children move out from home to school or to the community, they meet with other children too from different backgrounds and with different behaviours, interests and perceptions. They may begin to create friendships and become attached to their friends gradually through playing together and sharing ideas during socialisation. All these can affect other children's academic performance depending on individuals.

On peer collaborative learning, Rodgers (1997) argues that, children learn more with their peers since they are fully and freely exposed in their interactions to share ideas. These make them to acquire knowledge among themselves. Through sharing, peers can suggest good reading materials that some of them have read and give others ideas on where to find them thereby encouraging them to visit the library regularly. These strategies make reading more interesting and meaningful and can result to interest in the reading culture.

\section{Analysis and Discussion}

The study noticed that, the learners were brought up in an environment where the rate of reading is low. It is evident from the members of this community that most of them dropped out from school without the Metric. Since children learn through experience, it would be therefore difficult for them to develop such an interest if their community is not keen on it. In view of this, teachers need to use various strategies to get learners reading because the moment that these learners can develop an interest and also come to notice its benefits, they would be hooked and this would then transform the society to be one with a reading culture.

Based on the above, Nwabueze (2011) observes that that this may be a good reason for teachers, parents and peers to take it seriously in assisting to change a child's negative attitude towards reading by giving full support that can make the child to understand the importance of being proficient in reading. Thus, concludes that reading needs to be cultivated to become a habit and then attitudes, behaviours and character.

Given the legacy of the Bantu education, homes and communities are affected by the lack of a reading culture. This is in view of the illiteracy rate in South Africa. In one way or another, one would not expect the learners to have much interest in reading and therefore reading culture should be a night mare among the learners. However, Nssien (2008) observes that since the school is the second home for the learners, it becomes the responsibility and duty of teachers, particularly language teachers to inculcate a reading culture among learners.

Nelson Mandela and most South African parents are of the view that education is the only weapon that can unlock the misery of the nation. It is in this perspective that Banda (2009) argues that most South African parents send their children to former model $\mathrm{C}$ schools first and foremost because the language of learning and teaching is a global language. Secondly because there is justifiable evidence that the learners are motivated enough to carry on with their studies. It is in such a spirit that this researcher thinks that promoting an educational climate that facilitates motivation and the desire to read in children, is the spring board to academic success. Academic success also equates a useful and responsible life. All these can be achieved easily if the reading culture is instilled in learners at an early age.

In view of this, Ezc (2006) asserts that the role of a school is to be responsive to vast and variety needs of each child in the school environment. For example, they should provide a variety of high interest reading materials of various grade levels in the classroom: This can be accomplished by obtaining magazines, newspapers, books, dictionaries, encyclopaedias, and other reference materials that contain content that matches students' interests.

In conclusion, this means that for the learners to be successful academically, they need a proper exposure and appropriate strategies in reading to build and enhance student's foundation which can assist them to acquire other academic skills easily because they can contextualise the concepts from different fields of their studies. In this regard, learners may be able to understand the information and use it as a bridging gap between knowledge and ignorance (Nssien, 2008).

It should be important to note that Multilingualism has always been a major challenge to the development of literacy, reading culture, publishing and libraries in Africa. Almost every African government has to contend with multiple 
languages, a situation that impacts on communication, education and development in general (Tötemeyer, 2004). Being able to speak a language does not make one literate. Literacy requires that one should also be able to read and write the language spoken correctly and with ease. The definition of functional literacy is, "having the reading and writing skills necessary for everyday living and the workplace, equivalent to eight years of successful formal schooling in the mother tongue or preferred language of learning" (Hoffmann, 2008:11).

Moreover reading is a complex process. Learning to read is an important educational goal and the ability to read has a positive impact on school success, employability, independence, and autonomy, as well as providing a means for lifelong learning, entertainment, and introspection (Goodman, 1967). It enables learners to gain new knowledge, enjoy literature, and do everyday things that are part and parcel of modern life. Goodman (1967:135) claims that, "reading is a psycholinguistic guessing game. It involves "an interaction between thought and language". He writes that "efficient reading does not result from precise perception and identification of all elements, but from skill in selecting the fewest, most productive cues necessary to produce guesses which are right the first time." (Goodman, 1967: 126).

In addition, Falk (1973:386) states that "... for literate adult who already know how to read, reading is an active interaction of adults' knowledge of their language with the material, printed or written, that they perceive visually, the purpose is to comprehend meaning". For learners, just beginning to read with printed material, "reading can become just what it is for the adults". Peregoy and Boyle (2000:259) state that "reading is the most important activity in any language class. Peregoy and Boyle (2000:259) further state that reading is a source of information, a pleasurable activity and a means of consolidating and extending one's knowledge of the language."

Since reading depends on efficient word recognition and comprehension, instruction should develop reading skills and strategies, as well as build on learners' knowledge through the use of authentic text (Goodman, 1967). Teachers of language must understand the processes involved in reading and help learners develop habit of reading that will lead them to direct comprehension (Pang et al., 2003). This should not be done hurriedly; instead, it should be done steadily and continuously. Goodman (1967) describes the reading process convincingly when he states that: a) Readers develop sampling strategies to pick up the most useful and necessary graphic cues. b) They develop prediction strategies to get the underlying grammatical structures and to anticipate what they are likely to find in the print. c) They develop confirmation strategies to check on the validity of their predictions. d) They have correction strategies to use when their predictions do not work out and they need to reprocess the graphic, syntactic and semantic cues to get the meaning. (p.135). Therefore, reading instruction is crucial. Reading instruction needs to take into account different types of learners and their needs (Pang et al., 2003). Yet, a large percentage of ESL learners, even in the advanced levels of second language proficiency, fail to do as it should be expected on the English texts (Alptekin, 2006).

Traditional instruction methods and rules-based systems don't work for ESL learners so alternatives are necessary and the important parts of promoting culture of reading are as follows:

There has been great deal of interest in skimming over the past decade. According to Pennington (2008) skimming helps the reader to access the story schema so as to provide a referential context for the reading. In other words, skimming helps the reader to learn in advance what text the gist of the reading passage is, while reminding the reader of any background information and knowledge of how the writing is organized that will assist the reader in understanding the text. In addition to providing main idea to readers, other research (Melvin, 2006) also shows that enjoying through skim reading in the comfort of knowing it will enable readers to increase their overall reading speed.

Cooperative reading techniques were developed during the past two decades in an effort to shift attention and control in the reading classroom from correct answers toward the joint negotiation and co-construction of meaning from text. Evidence suggests that cooperative reading necessitates more collaborative, multidimensional and authentic assessment (Norato and Canon, 2008). Further, as time rapidly approaches the information age, technology assist cooperative reading will continue to become more and more prevalent. Besides, as our society becomes increasingly diverse, cooperative reading will become more widely used to integrate learners of varying races, ethnicities, ability levels, special education classifications such as EFL and ESL students to name a few of the many process of cooperative reading, as well as their interactions (Jay and Salisbury, 2000).

Furthermore, Jay and Salisbury (2000) believe that Piaget's (1983) theory of cognitive development was the theoretical framework for the Structured Controversy of cooperative reading technique. They believed that interacting with others helps learners to confront their own misconceptions. The work of Piaget and the belief that cognitive conflict lead to higher levels of reasoning and learning is the base of collaborative reading techniques. In the Piagetian tradition, cognitive development in a reading classroom is contingent on individuals confronting those who hold contradictory thoughts and claims, thereby creating conflicts that spur higher levels of reasoning (Williamson, 2010).

In addition, technology-supported cooperative reading is firmly grounded in a learner-centred constructivist approach to instruction and learning (Cook, 2010). Many cooperative learning techniques are grounded to some degree 
in constructivist principles. At the same time, a learner-centred constructivist approach to instruction has increased practitioners' demand for cooperative learning and cooperative reading techniques (Wiggins, 2006).

There is a host of work done on the Directed Reading-Thinking Activity and its importance for improving reading in general (Norato and Canon, 2008). According to Tierney et al. (1995), it is a strategy for building independent readers adding that this strategy has the potential to equip readers with the abilities to determine purposes for reading, examine reading materials, suspend judgments and make decisions. Similarly, Richardson and Morgan (1997) state that the Directed Reading-Thinking Activities engage students in higher order thinking skills making connections between interrelated elements of the text, justifying thought processes and drawing logical conclusions. Likewise, Jennings and Shepherd (1998) state that the Directed Reading- Thinking Activities help students become aware of the reading strategies, understand the reading process, and develop prediction skills. Along the same lines, Tankersley (2005) states that the Directed Reading-Thinking Activities extend reading to higher-order thought processes and provides teachers with a great deal about each student's ideas, thought processes, prior knowledge and thinking skills. Therefore, learners need to blend their own thinking with the information they read to comprehend what is between and beyond the lines.

\section{References}

Abongdia, J. F. A. (2013). Language Ideologies in Africa: Comparative Perspectives from Cameroon and South Africa. Thesis Doctor of Philosophy (Linguistics) in the Faculty of Arts, University of the Western Cape.

Ahamefule, K N. (2001). Psychology, the Science of Human behaviour. Enugur: Sages Publishers.

Allman, K. O. (2009). "Attitudes to Nigerian English among Lagos State Teachers: A Sociolinguistic Survey". Unpublished Ph.D. Dissertation, University of Ilorin.

Alptekin, C. (2006). Cultural familiarity in inferential and literal comprehension in L2 reading. System, 34, 494-508. URL: http://www.elsevier.com/locate/system Accessed 22 May 2014.

Banda, F. (2009). Critical perspectives on language planning and policy in Africa: Accounting for the notion of multilingualism. Stellenbosch Papers in Linguistics PLUS, 38: 1-11.

CAPS (2012) curriculum and Assessment Policy Statement (CAPS) intermediate phase First Additional Language.

Cook, V. J. (2010). The relationship between first and second language acquisition revisited. In Macaro, E. (ed.) The Continuum companion to second language acquisition (137-157). London: Continuum.

De Klerk, V. (2002). "Language issues in our schools: whose voice counts?" Perspectives in Education 20(1): 1-28.

Din Yanl, D. (2001). Global Understanding for Global English. Paper Given to Moscow.

Dudeney, A. (2003). Events Changes in the Layout of Affordances. Ecological Psychology 15: 19-25.

Ezc, C. J. (2000). Factors that Hinder Reading proficiency Among Primary School pupils in Lhiala Local Government Area. (Unpublished) Bsc. Research project. Department of Adult education. Nnamdi Azikiwe University, Awka.

Falk, S. (1973). Linguistics and Language: A Survey of Basic Concepts and Implication. Oxford: John Wiley and Sows.

Foncha, J. W. (2013). A Selective Investigation of the University of the Western Cape's Students and teachers attempts at Intercultural Communication: Exploring the connections between Intercultural Communication Competence and Identity Construction. Unpublished PhD thesis, University of the Western Cape.

Foncha, J. W. and Sivasubramaniam, S. (2014). The Links between Intercultural Communication Competence and Identity Construction in the University of Western Cape (UWC) Community. Mediterranean Journal of Social Sciences 5(10):376-385. ISSN 20399340 .

Gibbons, D. R. (2003). Treatment of Error in Second Language Writing Classes. Ann Arbor, Ml: University of Michigan.

Goodman, T. (1967). Psycholinguistic Universal in the Reading Process. Psycholinguistics and Reading. New York: Holt, Rinehart (2127).

Hoffmann, P. (2008). Education system is failing black learners, Cape Times.

Jay, B. C. and Salisbury-Glennon, J. (2000). Three decades of cooperative reading from theory to practice: implications for the 21st century. URL: http://www.scribd.com/doc/2879007/Cooperative-Reading-review-Bonk-and-SalisburyGlennon. Accessed 28 $8^{\text {th }}$ April 2014.

Jenkins, J. (2003). World Englishes: A Source Book for Students. In Routledge. P. (ed.) English Language: Introductions. London: Routledge.

Jennings, C. and Shepherd, J. (1998). Literacy and the Key Learning Areas: Successful Classroom Strategies. Australia: Eleanor Curtain Publishing. URL: http://www.rockingham.k12.va.us/English/shared/Directed\%20Reading\%20Thinking.pdf Accessed 13th May 2014.

Mackay, S. L. (2002). Teaching English as an International Language: Rethinking goals and Perspectives. New York: Oxford University Press.

Melvin, N. G. (2006). Skimming - Will it improve your reading? Retrieved July 14, 2014 http://www.google.com

Moerk, I. M. (1994). Developmental Change in Children is the Assessment of Intellectual Competence. London: Longman Publishers. New London Group, 1996. A Pedagogy of Multiliteracies: Designing social futures. Har.Ed.Rev. 66:60-92.

Norato, A. and Canon, J. (2008). Developing cognitive processes in teenagers through the reading of short stories. PROFILE, Issues in 
Teachers' Professional Development 9: 9-22.

Nssien, F. U. (2008). Reading Habits Skills. Uyoc: Abaam Publishing.

Nwabueze, A. (2011). Library Work with Research Children Young Adults /adolescent. Unpublished MA thesis.

Pang, E. S., Muaka, A., Bernhardt, E. B. and Kamil, M. L. (2003). Teaching reading. EDUCATIONAL PRACTICES SERIES-12. The International Academy of Education- IAE.

Pennington, M. (2008). How to Skim for Main Ideas. Retrieved July 14, 2014 http://www.google.com

Peregoy, S. F. and Boyle, O. F. (2000). English learners reading English: What we know, what we need to know. Theory into practice 39(4): 237- 247.

Piaget, J. (1983). "Piaget's theory". In Mussen, P. (ed.). Handbook of Child Psychology. 4th edition. New York: Wiley.

Pressley, M. (2002). Reading Instruction that Works: The Case for Balanced Teaching (2nd ed.). New York: Guilford.

Probyn, M; Murray, S; Botha, L; Boyta, P; Brooks, M; Westphal, V (2002). Minding the gaps - an investigation into policy and practice in four Eastern Cape districts. Perspectives in education 20(1): 21-36.

Richardson, J. S. and Morgan, R. F. (1997). Reading to Learn in the Content Areas. Belmont, CA: Wadsworth Publishing Company.

Rodgers, T. S. 1997. Partnership in Reading and Writing. London: Longman Publishers.

Satija, M. P. (2002). Reading and Book for Culture. Herald of Library Science. 41 (1 and 2): 55-59.

Sivasubramaniam, S. (2004). Constructivism in ElL: Issues and Insights for Teaching and Reasearch. Journal of English as an international 6(1): 30-65.

Smith, K. M. (2003). Emotions of English Language Attitudes in Building a Knowledge Society. Multicultural Education. 11(1): 46-53.

Tankersley, K. (2005). Literacy strategies for grades 4-12: reinforcing the threads of reading. Alexandria, VA: Association for Supervision and Curriculum Development.

Tötemeyer, A. J. (2004). "Awards for local language children's literature: worth the effort?" International Board on Books for Young People (IBBY) World Congress on "Books for Africa", Cape Town South Africa.

Trelease, J. (2006). How Non-Reading Students are Related to Their Non-Reading Parents and Teachers. URL: http://www.trelease-onreading.com. Accessed 22 March 2013.

Turners, J. (1997). The Influence of Classroom Contexts on Young Children's Motivation for Literacy. Reading Research Quarterly. 30(3): 410441.

Williamson, G. (2010). Vygotsky. URL: http://www.speech-therapy-information-and-resources.com/vygotsky.html Accessed 19th May 2014.

Wiggens, G. (2006). A Process Genre Model for Teaching writing, The English teaching forum, 43(3): 121-134.

Wood, T. (2004). The Five most Effective Ways to end Yor Son's Reading Problems. New York: McGraw. 